УДК 347.998 .85 (477) Україна

DOI https://doi.org/10.32837/pyuv.v2i4(29).455

\author{
О. В.Рафальська \\ orcid.org/0000-0001-5394-4150 \\ аспірант кафедри адміністративного права \\ Київського національного університету ілені Тараса Шевченка
}

\title{
ІНСТИТУТ МНОЖИННОСТІ В ЄВРОПЕЙСЬКІЙ ПРАКТИЦІ ЯК НОВИЙ ДЛЯ УКРАЇНСЬКОГО ЗАКОНОДАВСТВА
}

Розуміння і врахування світових тенденцій є вкрай важливим під час планування перетворень державного управління і місцевого самоврядування в Україні з огляду на процеси міжнародної інтеграції, у тому числі обраний керівництвом нашої держави євроінтеграційний курс [1, с. 95]. Це завдання набуває актуальності в контексті активізації адміністративної реформи.

На цей час у теорії юридичного процесу відсутня єдина концепція процесуальних форм захисту $[2$, с. $5,14-15$.$] , яка своєю чергою має вихід на$ питання про види юрисдикційних процесів. Класифікація позовів за характером захисту інтересів є актуальною в зв'язку із законотворчою діяльністю і уніфікацією процесуальних кодексів [3].

Процесуальне право зарубіжних країн завжди привертало увагу вчених та юристів й досить великий проміжок часу є предметом досліджень в аспекті інтеграції між державами в сфері життя суспільства, а також міжнародних та економічних зв'язків. Незважаючи на зближення та зумовленість правових систем, порядок здійснення правосуддя у адміністративних справах в різних країнах відрізняється, що зумовлює актуальність досліджень у цій сфері.

Опрацювання процесуальних елементів провадження має не тільки наукову, а й практичну природу. Розглядаючи деякі проблематичні аспекти судочинства, науковці досить часто звертаються до досвіду регулювання схожих питань в інших державах. Це допомагає не тільки визначити шляхи реформування національного законодавчого підгрунтя, а й достеменно дослідити вітчизняні інститути та виявити наявні у них дефекти.

Така актуальність у дослідженнях призводить до появи великої кількості літературних джерел, які присвячені аналізу та опису міжнародного процесу.

Міжнародною доктриною вивчення інституту множинності найчастіше проявляється через розгляд таких категоріальних понять, як «груповий (колективний) позов», «масовий позов» або ж «процесуальна співучасть».

Груповий позов за своєю процесуальною конструкцією відрізняється як від позовів на захист інтересів невизначеного кола осіб [4], так і від процесуальної співучасті [5].
Сам термін «група осіб» означає, що склад групи буде визначено, i, відповідно, на момент винесення рішення по груповому позову склад її буде персоніфікований, що дає можливість отримувати присудження членам цієї групи майнового характеру за вимогами.

Структура позовів на захист невизначеного кола осіб зумовлює, що склад характерної групи не можна чітко та достеменно виділити, а вирішення по справі має преюдиційний характер, а тому рішення щодо спору має можливість розгляду шляхом внесення позову в індивідуальному порядку та в окремому судовому провадженні. У рамках такої форми процесуального судочинства захищається публічний, суспільний інтерес, який не може бути приватним без індивідуального носія [6, с. 16].

Під час використання групового позову одночасно може захищатися як приватний, так і публічний інтерес, оскільки можливе стягнення за таким позовом на користь членів її групи. Необхідність розмежування цих видів позовів у правозастосовній діяльності пов'язана також 3 можливістю подачі прокурором позовів у справах про захист невизначеного кола осіб незалежно від предмета спору.

Групові позови у Сполучених Штатах Америки прийнято розділяти на два види: по-перше, групові позови, які об’єднують велику кількість дрібних вимог різних позивачів, тримання яких в суді в порядку пред'явлення особистого позову $\epsilon$ невигідним з урахуванням високої ціни судових витрат в США, як і в більшості інших країн загального права; по-друге, групові позови про накладення судової заборони, які пред'являються від імені учасників численних груп осіб, права і законні інтереси яких були порушені в результаті протиправного діяння відповідача [7].

Законодавче зазначення процесу за груповим позовом в США зводиться до його характеристики як специфічного виду судочинства, відповідно до якого декілька осіб мають однотипні вимоги до суду, тому об'єднуються в групу, щоб пред'явити ix й таким чином убезпечити власні законні інтереси та відновити порушені права швидко, чітко та ефективно.

Неодномоментим є те, що коли особа звертається з таким позовом до суду, вона зобов'язується 
надати згоду на участь у судовому розгляді як представника багаточисельної групи, а для того щоб він мав змову виступити, він повинен бути затверджений судом.

В аспекті тлумачення процесуальних норм щодо групових позовів існують досить розгалужені бачення позову, які пропонуються американськими адвокатами задля рекламних цілей. Одним із популярних визначень є таке: груповий позов - це позов, у разі пред'явлення якого представник групи може вимагати судового захисту прав і інтересів всіх інших осіб, які зазнали подібного заподіяння шкоди з боку одного і того ж правопорушника. Групові позови забезпечують позивачам з невеликим розміром позовних вимог отримання відшкодування шкоди з боку відповідача.

Так, у США дійсно цей інститут набув найбільшого розповсюдження, а тому й здобув свої окремі риси та ознаки як, наприклад, неабиякі винагороди для адвокатів як представників у процесі та чималі санкції для відповідачів. Це доволі непоганий приклад класичної моделі (class actions), але й викликає велику кількість негативного ставлення щодо його запровадження в Європі. Тому резолюцією Європейського парламенту «Щодо послідовного європейського підходу до колективного захисту прав» зазначається, що «Європа має стриматися від запровадження системи групових позовів американського зразка або іншої системи, що не відповідає традиціям європейського права» [8].

А втім, у Європі все-таки впроваджено деякі форми захисту колективних прав та інтересів. Директивою 98/27/ЄС Європарламенту та Ради від 1998 року щодо судових заборон передбачено можливості звернення з представницькими позовами щодо захисту колективних прав споживачів та припинення дій, які порушують ці права [9].

Щодо Англії, то, на відміну від вітчизняної системи процесуального права, яка проявляються у відсутності таких понять, як груповий, колективний, масовий позов, англійське процесуальне право тлумачить багато таких визначень.

Відповідно до 5 Правил судів графств Англії представницький позов - це позовна заява, відповідно до якої ініціюється судовий розгляд щодо безлічі осіб, який може бути призначений судом на захист одного і більше учасників численної групи, які виступають як представники всіх учасників численної групи або всіх учасників групи відповідачів, за винятком одного або кількох з них, а в 7 Правилах цивільного процесу Англії він визначається як позов, в якому з дозволу суду об'єднані позовні вимоги в захист або щодо двох i більше осіб, які виступають як позивачі або відповідачі.

Крім того, правило включає норму, відповідно до якої об’єднання вимог позивачів або відповіда- чів в одному процесі, за певних дієвих обставин може здійснюватись без дозволу суду. Норми процесу в англійському законодавстві регламентують, що під час вирішення справи по суті в аспекті представницького позову суд зобов'язується керуватись принципами досягнення ефективного та чіткого вирішення спору.

Позов громадських об’єднань відомий як українському, так і німецькому адміністративно-процесуальному праву, згідно з яким під адміністративним позовом громадських об'єднань розуміється адміністративний позов, поданий громадським об'єднанням на захист не власних, а чужих інтересів. Варто констатувати, що колективний адміністративний позов у німецькому процесуальному законодавстві, на відміну від вітчизняного, відсутній.

Виникнення конфліктів, які охоплюють питання права або ж певного факту, який, зазвичай, буде загальним для великого кола осіб, зумовлює функціонування інституту процесуальної співучасті, тобто колективного позову, що застосовується в будь-якій сфері правового регулювання життя суспільства.

Запровадження цього інституту є досить раціональним для національного законодавства, але слід зазначити щодо розгалуження думок науковців навіть щодо питання поняття «груповий позов». Деякі сприймають його тлумачення як звернення, що реалізує себе від імені групи осіб щодо розгляду спору, який виник на підставі певного юридичного факту або ж є вимогою про поновлення порушеного права, зміну статусу осіб, яке заявлене в інтересах всієї групи осіб [10, с. 10]. Інші ж вважають, що це вимога щодо захисту особистих суб'єктивних порушених прав як учасників великої групи осіб [11, с. 8-9].

Також існує думка щодо ототожнення групового позову та процесуальної співучасті, адже за юридичною природою його можна віднести до активної співучасті з усіма процесуальними ознаками цього інституту [12, с. 39-40].

Процесуальну співучасть можна визначити як участь у одній справі кількох осіб як збоку позивача, так і з боку відповідача. Слід зазначити, що цей інститут дійсно є близьким до групового позову саме через таку їхню спільну ознаку, як множинність.

Загалом можна з точністю стверджувати, що груповий позов не єдиний спосіб захисту прав та інтересів групи осіб. М. Єлісєєв під час узагальнення всієї світової практики зазначив, що для вирішення таких ситуацій повинні використовуватись певні правові конструкції: класичний інститут співучасті; стороною може виступати організація, яка наділена правом захисту; державний орган також може бути наділений правом пред'явлення позову на захист; провадження за однаковими 
справами може бути зосередженим в одному органі юстиції; групове провадження, яке буде поєднувати в собі ознаки процесуальної співучасті та судового представництва [13, с. 472-477].

Процесуальне право $є$ складовою частиною системи права будь-якої держави незалежно від того, до якої правової сім’ї - загального, романогерманського, традиційного чи змішаного права налужить відповідне законодавство.

До законодавчих актів якої б держави світу не звернутись, всюди є можливість виділити однотипні принципи, норми й правила.

Сторонам, які особисто присутні на засіданні, надається можливість представляти докази й наводити певні аргументи щодо захисту відповідної точки зору, а також спростовувати докази і аргументи іншої сторони по справі.

Слід зазначити, що судочинство за масовим позовом представляє собою процедуру вирішення певних посталих суперечок, оскільки деякі суб'єкти судового захисту під час вирішення питання щодо його представництва судом зазвичай не приймають безпосередньої участі в судовому розгляді. Підставою для порушення такої адміністративної справи може бути позовна заява на захист або стосовно чисельної кількості осіб.

Необхідно зазначити, що серед вчених-процесуалістів, так само як і в рядах законодавців та суддів, на цей момент немає єдиного загального розуміння того, що повинно представляти собою адміністративне судочинство в аспекті масових позовів. Якщо для науковців такий стан речей $€$ звичайною нормою, то для законодавців та суддів удосконалення та більш точні визначення будуть вдалішим кроком для практичної діяльності.

Будь-який позов, який поданий до суду та містить законні вимоги щодо надання захисту прав та інтересів безлічі інших осіб, можна вважати масовим, але іноді питання викликає саме поняття «велика кількість осіб». Відсутність допустимої межі щодо чисельності позивачів у визначеному випадку може призвести до участі дійсно кількісної групи, яка буде нараховувати невимовно велику кількість учасників.

Про ті чи інші особливості позову з елементами множинності можна та потрібно дискутувати. Створення такого механізму, який би був досить підходящим чи навіть ідеальним на практиці та який одразу дав максимально ефективний результат під час впровадження, парадоксально. Проте їх застосування для захисту прав та інтересів великого кола осіб має позитивні наслідки: розширення громадянам доступу до суду, зменшення робочого навантаження на суддів, а також процесуальну економність.

Отже, слід констатувати, що англійське, німецьке, французьке право є істотним передумовником у розвитку вітчизняного права. В зв'язку з цим вивчення зарубіжного судочинства забезпечує більш глибоке розуміння вітчизняних процесуальних інститутів. Ряд проблем, з якими стикаються суди і учасники процесу під час розгляду адміністративних справ, доступність засобів судового захисту, завантаженість судів, тривалість і економічна дезорієнтованість є загальними для багатьох країн. Дослідження методів їх вирішення в різних правових системах дає цінні результати, які слід використовувати під час проведення правових реформ з метою вдосконалення адміністративного судочинства.

Міжнародна співпраця, стрімка економічна інтеграція вимагають створення єдиного правового простору, атрибутом якого є однакове міждержавне регулювання найбільш важливих питань судочинства. Виявлені в результаті порівняльного аналізу подібності та відмінності в рішенні стикових питань адміністративного процесу мають міжнаціональний характер і представляють для держав взаємний інтерес.

Сьогодні актуальність впровадження в нашій країні таких процедур не є одномоментною. Під час аналізу позову як групового процедура розгляду буде відбуватись в одній справі, а вимоги окремих осіб групи задовольнятимуться спрощеним способом. Держави - члени ЄС рухаються шляхом створення оптимального механізму для вирішення спорів із численною групою осіб. Тому вивчення та дослідження досвіду відповідно до цього питання та адаптація групового позову до національного законодавства надасть Україні можливість для створення ефективного процесуального судового механізму захисту прав, свобод та інтересів громадянина.

\section{Jimepamypa}

1. Кравченко С.О. Державно-управлінські реформи : теоретико-методологічне обгрунтування та напрями впровадження : монографія. Київ : НАДУ, 2008. 296 с.

2. Шубина Татьяна Борисовна. Теоретические проблемы защиты права : дис. ... канд. юрид. наук : 12.00.01 : Caмapa, 1997. 228 c.

3. Чугурова Т.В. Процессуальные формы защиты публичных интересов в российском праве : дисс...канд. юрид. наук. Самара, 2007.С. 216.

4. Батаева Н. Судебная защита прав и интересов неопределенного круга лиц : дисс... канд. юрид. наук. Москва. 1999. С. 164.

5. Лесницкая Л.Ф. Проблемы доступности и эффективности правосудия в арбитражном и гражданском судопроизводстве. Материаль Всероссийской научнопрактической конференции. Москва. 2001. С. 357.

6. Павлушина А.А. Указ. Соч. с. 188

7. Hazard G.C. jr., Taruffo M. American Civil Procedure, Yale University. 1992. P. 159

8. European Parliament resolution of 2 February 2012 on 'Towards a Coherent European Approach to Collective Redress', European Parliament. URL: http://www.europarl.europa.eu/sides/getDoc. do? pubRef $=-/ /$ EP $/ /$ TEXT + TA + P $7-\mathrm{TA}-2012$ $0021+0+\mathrm{DOC}+\mathrm{XML}+\mathrm{V} 0 / / \mathrm{EN}$. 
9. Ларссон П. Груповий позов у Свропейському союзі / Пер Ларссон // Захист невизначеного кола споживачів в ЄС та в Україні /Спільнота споживачів та громадянські об'єднання. Київ, 2009. URL: http:// www.cjnsumerrinfo.org.ua/upload/iblock/b62/class_ action eu ukraine.pdf.

10. Аболонин Г.О. Групповые иски в гражданском процессе : автореф. дис. ... на соискание учен. степени канд. юрид. наук : спец. 12.00.15 «Гражданский процесс, арбитражный процесс». Екатеринбург, $1999.28 \mathrm{c}$.

11. Журбин Б.А. Процессуальные особенности рассмотрения судами дел по групповым и производным искам : автореф. дис. ... на соискание учен. степени канд. юрид. наук : спец. 12.00.15 «Гражданский процесс, арбитражный процесс». Саратов, 2009. 25 с.

12. Миколаец В. Понятие и признаки групового иска. Legea si viata. № 5/3. 2014. C. 38-41.

13. Елисеев Н.Г. Гражданское процессуальное право зарубежных стран : учебник. 2-е изд., перераб. и доп. Москва : Проспект, 2004. 624 с.

\section{Анотація}

Рафальська О. В. Інститут множинності в європейській практиці як новий для українського законодавства. - Стаття.

У статті автор досліджує питання, пов'язані з поняттям та сутністю інституту множинності в адміністративному процесі України. Стаття присвячена актуальній проблематиці, що характеризується міждисциплінарністю. Зазначене також підтверджується метою статті - проаналізувати сучасну ситуацію процесуальної реалізації інституту множинності на міжнародній арені та в адміністративному процесі України, розглянути ключові у юридичній науці позиції, визначити на глибинному рівні особливості розуміння досліджуваного концепту.

Проблемі визначення та затвердження інституту множинності в адміністративному судочинстві присвячено досить велику кількість наукових праць. Однак майже відсутні грунтовні дослідження, пов' язані з особливостями цієї концепції.

На основі відповідної судової практики та наукової теоретичної бази було проаналізовано та систематизовано основні підходи до визначення цього поняття. Сформульовано важливий висновок про те, що у контексті правозастосування така ідея наповнюється якісно новим змістом, який відповідає як національній, так і міжнародній спільноті. А враховуючи вищезазначене, це дослідження є актуальним та важливим для системи уявлень про інститут процесуальної співучасті.

У статті розглядаються групові позови в системі процесуальних форм захисту. Сформульовані особливості цієї форми захисту в контексті процесуальної множинності. У цій роботі досліджено низку наукових підходів до визначення поняття «процесуальна участь», досліджено його правову природу. Увага приділяється питанням розмежування суміжних процесуальних інститутів - процесуальної участі та групового позову. Автор досліджує досвід проведення інституційних класових дій у зарубіжних країнах та можливість його використання в процесуальному законодавстві
України, визначає особливості провадження за груповим позовом.

Здійснена детальна характеристика основних складових елементів права на судовий захист за множинності учасників у процесі, а також обгрунтовано те, що це право можна реалізувати тільки за наявності ефективного механізму судового захисту.

Ключові слова: процесуальне законодавство, процесуальна співучасть, адміністративне судочинство, множинність, груповий позов.

\section{Summary}

Rafalska O. V. Institute of plurality in European practice as a new to Ukrainian legislation. - Article.

In the article given to consideration an author investigates the questions related to the concept and essence of institute of multiplicity in the administrative process of Ukraine. The article is sanctified to the actual range of problems, that is characterized by analyze in different disciplines. What is marked is also confirmed by the aim of the article - to analyze the modern situation of judicial realization of institute of multiplicity in the international arena and in the administrative process of Ukraine, to consider key in legal science positions, define the features of understanding of the investigated concept at deep level.

The problem of decision and claim of institute of multiplicity in the administrative rule-making it was sanctified to plenty enough of scientific works. However, almost absent researches related to the features of this conception.

On the basis of corresponding judicial practice and scientific theoretical base it was analyzed and systematized the fixed assets to the decision of this concept. An important conclusion is set forth that in the context of application of right, such idea is filled with qualitatively new maintenance that answers as to national so international association. And, taking into account, this above-mentioned research is actual and important for the system of ideas about the institute of judicial participation.

In the article group lawsuits are examined in the system of judicial forms of defense. The set forth features of this form of defense are in the context of judicial multiplicity. In this work the row of the scientific going is investigational near the decision of concept "judicial participation", investigational him legal nature. Paid attention to the questions of differentiation of contiguous judicial institutes - judicial participation and group lawsuit. An author investigates experience of realization of institutional class actions in foreign countries and possibility of it's use in the judicial legislation of Ukraine, determines the features of realization by group.

An author investigates experience of realization of institutional class actions and possibility of it's use in the judicial legislation of Ukraine, determines the features of realization.

It was carried out detailed description of basic component elements of right of judicial defense at multiplicity of participants in a process, and also reasonably that this right can be realized only at presence of effective mechanism of judicial defense.

Key words: procedural law, judicial administrative process, procedural participation, administrative legal proceedings, plurality, class action. 